\title{
Comparison of methods for revegetation of vehicle tracks in High Arctic tundra on Svalbard ${ }^{1}$
}

\author{
Magne Neby, Philipp Semenchuk, Erica Neby, and Elisabeth J. Cooper
}

\begin{abstract}
Natural regeneration after anthropogenic disturbance is slow in the tundra biome, but assisted regeneration can help speed up this process. A tracked off-road vehicle damaged a High Arctic dwarf shrub heath in Svalbard in May 2009, drastically reducing the vegetation cover, soil seed banks, and incoming seed rain. We assisted regeneration the following year using six different revegetation treatments and monitored their effects one month, and one and eight years after their application. By 2018, all treatments still had lower vegetation cover and limited species composition than the undamaged reference vegetation. The fertiliser treatment was the most effective in restoring vegetation cover (71\% vegetation cover, of which $62 \%$ were bryophytes and $38 \%$ were vascular plant species). Compared to the reference plots (98\% vegetation cover, of which $32 \%$ were bryophytes and $66 \%$ were vascular plant species), the composition of the disturbed vegetation was still far from regenerated to its original state nine years after the tracks were made. The slow regrowth demonstrated in this study underlines the importance of avoiding the disturbance of fragile tundra and implementing and upholding regulations that restrict or ban such disturbances.
\end{abstract}

Key words: Arctic, revegetation, Svalbard, plant community, restoration.

Résumé : La régénération naturelle après une perturbation anthropique est lente dans le biome de la toundra, mais la régénération assistée peut aider à accélérer le processus. Un véhicule tout-terrain à chenilles a endommagé une lande d'arbustes nains du HautArctique au Svalbard en mai 2009, réduisant considérablement la couverture végétale, la banque de graines du sol et la dispersion aérienne des graines à venir. Les auteurs ont assisté la régénération l'année suivante en utilisant six traitements de revégétalisation différents et suivi leurs effets un mois, puis un et huit ans après leur application. En 2018, la couverture végétale était toujours inférieure et la composition en espèce, limitée, par rapport à la végétation de référence non endommagée, malgré les différents traitements. Le traitement à base d'engrais était le plus efficace pour restaurer le couvert végétal (71\% de couverture végétale, dont $62 \%$ de bryophytes et $38 \%$ d'espèces de plantes vasculaires). Par rapport aux parcelles de référence (98\% de couverture végétale, dont $32 \%$ de bryophytes et 66 \% d'espèces de plantes vasculaires), la composition de la végétation perturbée était encore loin d'être régénérée à son état d'origine, neuf ans après que les traces ont été laissées par les chenilles. La lenteur de la régénération démontrée dans cette étude souligne l'importance d'éviter de perturber la toundra fragile, et de mettre en œuvre et de faire

\footnotetext{
Received 9 April 2021. Accepted 14 October 2021.
}

M. Neby. Department of Applied Ecology, Inland Norway University of Applied Sciences, Koppang, Norway.

P. Semenchuk. Department of Botany and Biodiversity Research, University of Vienna, Vienna 1030, Austria; Department of Arctic and Marine Biology, UiT - The Arctic University of Norway, N-9037, Troms $\emptyset$, Norway.

E. Neby and E.J. Cooper. Department of Arctic and Marine Biology, UiT - The Arctic University of Norway, N-9037, Troms $\emptyset$, Norway.

Corresponding author: Magne Neby (e-mail: magne.neby@inn.no).

${ }^{1}$ This paper is part of a Special Issue entitled: Impacts of climate change on tundra ecosystems: Three decades of results from the International Tundra Experiment (ITEX).

Copyright remains with the author(s) or their institution(s). This work is licensed under a Creative Commons Attribution 4.0 International License (CC BY 4.0) http://creativecommons.org/licenses/by/4.0/deed.en_GB, which permits unrestricted use, distribution, and reproduction in any medium, provided the original author(s) and source are credited. 
respecter les réglementations limitant ou interdisant ces perturbations. [Traduit par la Rédaction]

Mots-clés : Arctique, régénération assistée, Svalbard, communauté végétale, restauration.

\section{Introduction}

Natural regeneration in cold-dominated ecosystems is slow (Babb and Bliss 1974; Forbes and Jefferies 1999; Forbes et al. 2001), rendering the landscape less resilient to anthropogenic disturbance (Rickard and Brown 1974; Komarkova 1983; Walker and Walker 1991; Urbanska and Chambers 2002; Krautzer et al. 2012). For instance, it took up to 75 years to re-establish complete vegetation cover after removing mesic above-ground vegetation, roots, and soil in northern Alaska (Forbes et al. 2001). However, it might take several hundred years or more for a disturbed area to return to its original vegetation composition after disturbance, if at all, and plant diversity might still be lower than in undisturbed areas (Komarkova 1983; Forbes and Jefferies 1999).

Off-road tracked vehicles are commonly and extensively used in various industries, and by military, management personnel, and scientists throughout the Arctic. Since the 1950s, regulations have severely restricted their use with general rules and have established protected areas where they were banned. For instance, more than $60 \%$ of the land on Svalbard is currently protected and the use of vehicles is strictly regulated. However, the long history of coal mining and drilling (Theisen and Brude 1998) has left many historic vehicle tracks and other surface disturbances leading to linear or patchy scars on the tundra that may facilitate erosion, drainage, and further expansion of vegetation damage.

In addition to these long-term historical impacts, humans are increasingly disturbing fragile Arctic vegetation and landscapes (Walker and Walker, 1991; Forbes et al. 2001). After a change from coal mining as the main economic activity in Svalbard, tundra disturbance today is mainly linked to a growing human population (e.g. roads, drainage, residences, and related installations), as well as research and tourism. Large double-tracked vehicles are used to transport heavy materials (for moving ready-constructed cabins, mining machinery, etc.), whereas smaller vehicles (snowmobiles) are commonly and increasingly used for recreational purposes. Although driving on snow-covered frozen ground has little to no effect on soil and vegetation, the use of vehicles on unfrozen and non-snow-covered tundra directly or indirectly leads to vegetation removal, soil erosion, increased permafrost thaw depth, water runoff, nutrient leaching, and more (Rickard and Brown 1974; Abele et al. 1984; Felix and Raynolds 1989; Slaughter et al. 1990; Racine and Ahlstrand 1991; Forbes 1992; Emers et al. 1995; Kevan et al. 1995; Forbes et al. 2001; Li et al. 2007). Disturbances caused by vehicle tracks may be visible in the tundra for many decades (Forbes et al. 2001). Thus, damage prevention measures should be prioritised for management. To counterbalance such anthropogenic vegetation disturbances, an understanding of practical revegetation techniques on Svalbard is needed but is currently lacking.

Assisted regeneration may accelerate natural regrowth and reduce or even reverse damage to the original vegetation (MEA, 2005; Suding, 2011). Many studies have aimed to identify the best techniques and methods to assist revegetation in the tundra biome in general (Babb and Bliss 1974; Firlotte and Staniforth 1995; Forbes and McKendrick 2002; Mehlhoop et al. 2018). In recent decades, a refinement of the desired outcomes of such assisted regeneration activities has also been developed. For instance, while the rehabilitation of the original plant species composition may be the goal in some areas and under certain contexts, the reestablishment of vegetation cover, irrespective of its composition, may suffice in other areas or contexts. Facilitating the return of the original plant species 
composition requires more sophisticated methods. It is typically slower than primarily aiming for non-species-specific plant cover (Forbes et al. 2001) and requires a better understanding of the ecology of the habitat's species (Deshaies et al. 2009). Thus, the optimal practice is very context-specific, and the most appropriate treatments may vary depending on the community or ecosystem in question.

Every restoration method studied during the last few decades has yielded different results and has its own shortcomings (Firlotte and Staniforth 1995; Forbes and McKendrick 2002). In cold, nutrient-poor environments, for instance, fertiliser addition has been shown to relieve nutrient limitation and increase plant growth (Onipchenko et al. 2012; $\mathrm{Gu}$ and Grogan 2020). Furthermore, placing fibre cloths over disturbed areas increases temperature and moisture and has been shown to create safe sites for propagule germination and plant species establishment (Stetson 1996). Another study showed that tilling of devegetated areas activates the natural seed bank and generally increases soil aeration (Wilson and Gerry 1995), especially in cases where the disturbance resulted in soil compression. Additionally, the sowing of seeds, cuttings, and other propagules has been applied to create a fast replacement for removed vegetation (Chapin and Chapin 1980; Barak et al. 2017; Vloon et al. 2021). Finally, an early revegetation study near Longyearbyen (close to the field site we are reporting on here) was conducted in 1980 by the local authority, focusing on the sowing of introduced grass species (Låg 1986).

All the methods outlined here accelerate the re-appearance of any vegetation, irrespective of species composition (Chapin and Chapin 1980; Densmore 1992; Forbes et al. 2001). However, undesired effects have also been reported, such as the creation of atypical species assemblages or composition after fertiliser addition (Klokk and Rønning 1987), or naturalised stands of introduced species after sowing non-native seeds (Densmore 1992; Hagen et al. 2014). Such side effects are commonly accepted as an unavoidable trade-off in assisted regeneration in the tundra for users causing disturbances (e.g. industry, military), as the main aim is usually to bring back just enough vegetation cover preferably using local species to prevent erosion and expansion of disturbed patches in the most cost-effective manner possible (cf. Forbes et al. 2001, Forbes and McKendrick 2002). Just how undesirable these artefacts are depends on the specific case and on the practitioners' and stakeholders' goals, expectations, and time frames, making the choice of method complex. A thorough evaluation of each method's effects, side effects, and best practices will be necessary for choosing the optimal strategy for each site.

Despite numerous ecological restoration and rehabilitation studies, relatively few observations from specific ecosystems have limited meaningful comparisons. Thus, even simple experiments represent valuable contributions to the literature towards more rigorous estimations of revegetation time and (or) success. Similarly, a general lack of long-term post-treatment and (or) systematic monitoring challenges the interpretation and applicability of results for adaptive management (Bash and Ryan 2002; Miller and Hobbs 2007; Hagen and Evju 2013). However, see the circumpolar review comparing post-treatment conditions using many common assisted revegetation techniques by Forbes and McKendrick (2002).

Here, we test which of the outlined commonly used assisted regeneration techniques may be suitable for regenerating damaged vegetation, specifically in High Arctic Svalbard. We describe their potential side effects in terms of vegetation composition, an essential factor not only for the well-being of the ecosystem, but also for the eco-conscious community visiting and living near our field site. We applied these methods to devegetated tracks in the tundra, which were accidentally created by a large double-tracked off-road vehicle driving unduly late in the spring, that is, when snowmelt and soil thawing were very advanced and the tundra was vulnerable to disturbance. We report the revegetation of tracks 1, 2, and 9 years after the disturbance (i.e., one month, and one and eight years after 
their treatments were applied). Our findings are relevant for stakeholders interested in or in need of assisted regeneration of damage to tundra in Svalbard after severe disturbance.

\section{Methods}

Study area

The study site was a Cassiope heath, classified as a Cassiope tetragona (L.) D. Don. tundra (Elvebakk 2005), which corresponds to the Cassiope tetragona - Dryadetum octopetalae Rübel phytosociological association (Hadač 1946; Hadač 1989). The most abundant vascular plant species in the study area were Cassiope tetragona , Bistorta vivipara (L.) Delarbre, Dryas octopetala L., and Salix polaris Wahlenb. The site is situated in bioclimatic zone C, the middle Arctic tundra zone (Walker et al. 2005), near Longyearbyen, Svalbard, High Arctic Norway. The annual average temperature and precipitation during $1976-2020$ were $-4.7^{\circ} \mathrm{C}$ and $196 \mathrm{~mm}$, respectively, with most of the precipitation falling during winter (MET Norway 2021). The bedrock consists of flat-lying sandstone, silt, shale, and large fluvial deposits with active alluvial plains and fans nearby. The growing season is approximately 70 days (Rozema et al. 2009), with an average summer air temperature (1 June-31 August 1976-2020) of $5.1^{\circ} \mathrm{C}$ (MET Norway 2021).

The study site is located on the south side of Adventdalen $\left(78^{\circ} 10^{\prime} \mathrm{N}, 16^{\circ} 02^{\prime} \mathrm{E}\right), 25 \mathrm{~m}$ above sea level, and was selected because a double-tracked off-road vehicle left scars in the landscape in May 2009. The two parallel tracks were each approximately $47 \mathrm{~m}$ long, $0.5 \mathrm{~m}$ wide, and $2 \mathrm{~m}$ apart. Vegetation cover was greatly reduced in the tracks compared with the undisturbed vegetation in the surrounding area (see Fig. 1). Within the tracks, seed density in the soil seed bank was lower and seed influx was reduced compared with the surrounding intact vegetation (Fig. 2 and Appendices A and B). Soil density was relatively lower in the tracks than in the intact vegetation; therefore, it seems that the vehicle may have removed soil with attached vegetation rather than compressed it (Appendix C).

\section{Field measurements}

In June 2010, we installed 80 permanent $35 \times 35 \mathrm{~cm}$ quadratic plots distributed within the vehicle tracks (see Supplementary Fig. $S 1^{1}$ ). The size of the plots was determined by the width of the vehicle tracks, and the $35 \times 35 \mathrm{~cm}$ squares fit well without being too close to the track edges. The criteria for selecting the plots were made opportunistically and adjusted according to the soil and topographic conditions inside the tracks, which were sometimes unsuitable (i.e., parts which were more rocky or depressed, leading to waterlogging, than the bulk of the tracks were excluded). The plots were placed along suitable zones. The selected plots were approximately $10-200 \mathrm{~cm}$ apart and permanently marked with labelled plastic sticks in two corners so that we could place a quadrat/frame on the same location in the future. Ten of the initially selected plots were excluded because of unforeseen waterlogging after the first rain, resulting in a total of 70 permanent plots.

To document the disturbance to the vegetation caused by the vehicle tracks prior to experimental treatment application, we recorded the vegetation composition within (disturbed vegetation) and outside (intact, reference vegetation) vehicle tracks (Supplementary Table S1 ${ }^{1}$ ) using the point-frame method during $23-30$ June 2010. Outside the tracks (reference vegetation), we used 11 approximately equally spaced plots about $2 \mathrm{~m}$ away from the tracks. These plots were evenly distributed along the entire length of the tracks, with five plots on one side and six plots on the other side. Inside the tracks (disturbed vegetation), we used the 70 experimental plots previously described (prior to

\footnotetext{
${ }^{1}$ Supplementary data are available with the article at https://doi.org/10.1139/as-2021-0016.
} 
Fig. 1. Showing the vehicle tracks in June 2010 in Adventdalen, Svalbard. Vegetation cover was clearly reduced in the tracks compared to the surrounding vegetation. Here, showing the multiple pairs of plastic sticks, before the sticks were cut, marking each plot. Marker sticks were cut at ground level and left in place for the eight year duration of the study, and remain in place for future monitoring. The photo was taken soon after snow had melted. Photo credit: Erica Neby.

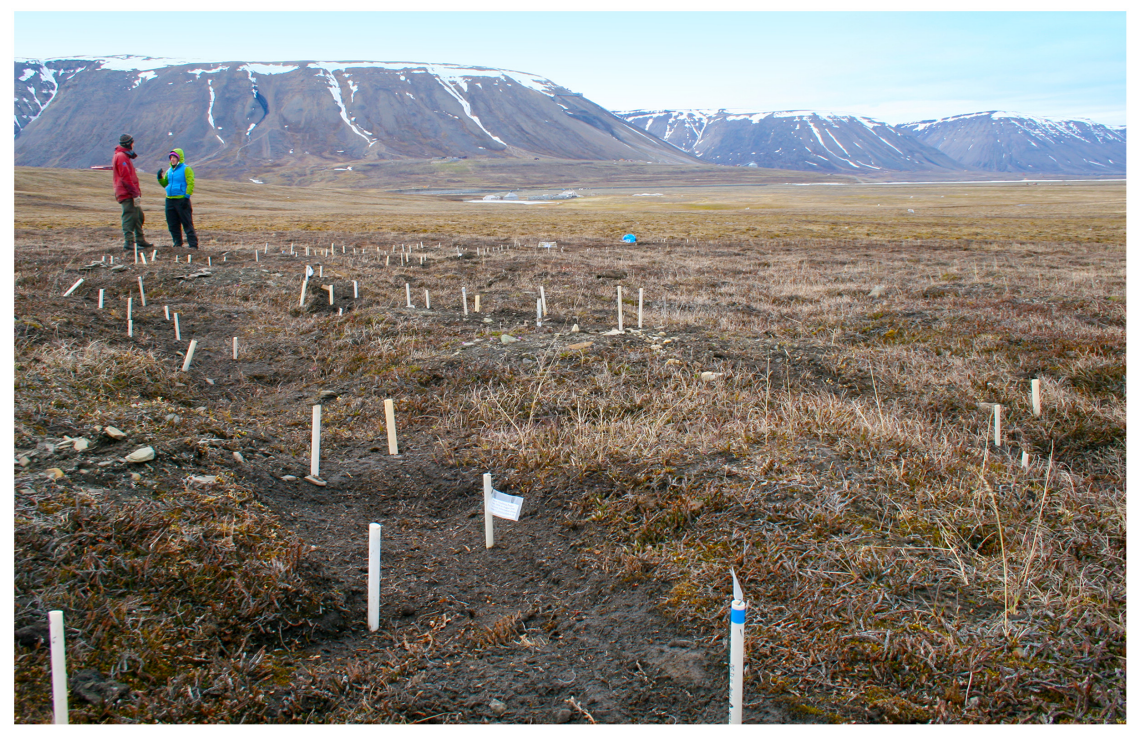

treatment addition). We used point-frame quadrats of size $35 \times 35 \mathrm{~cm}$, with strings spun across the frames every $5 \mathrm{~cm}$, resulting in a total of 25 string crossings per frame. At each string crossing, a wooden pin was carefully attached vertically through the vegetation. Each plant touching the pin (i.e., each "hit") was noted for each vascular species or species group until we reached the ground layer (bryophyte, fungi, bare ground, or droppings), which we also recorded. This resulted in up to three "hits" per pin in the reference and up to two "hits" per pin in the disturbed vegetation. For "hits" without vegetation cover, we also noted whether they were on bare ground, fungi, or animal droppings.

In July 2010, six different treatments were applied to the 70 plots, with 10 replicates per treatment and an unmodified control (Supplementary Fig. S1 $1^{1}$ ). The six treatments were applied only once at the beginning of the experiment in July 2010 and were not repeated thereafter. The allocation of treatment type to each plot was randomised.

To avoid edge effects from the treatments, we monitored the vegetation only in the centre $20 \mathrm{~cm} \times 20 \mathrm{~cm}$ of the plots. We performed this regularly during the growing seasons of 2010 and 2011 (see Supplementary Fig. S2 ${ }^{1}$, Fig. 3, temporal development) and at peak season in 2018 ( 20 July 2018) in the following way. Each plot inside the tracks was divided into nine equally sized subplots by using a portable square dissected with equally spaced strings (Supplementary Fig. S3 ${ }^{1}$ ). In each subplot, the percent cover of plant species was documented as visual estimates on a $1 \%$ scale, looking from above, with the maximum cover being $100 \%$ per subplot and species, resulting in more than $100 \%$ cover when summing the cover across all species.

Young graminoids and bryophytes were not identified to the species level and were, therefore, treated as two groups. However, the most common bryophytes in the area are Sanionia uncinata, Tomentypnum nitens, Hylocomium splendens, Dicranum and Distichium spp., Polytrichum spp., and Aulacomnium spp. (Mörsdorf and Cooper 2021), and we assumed that the species in the experimental plots were the same. Sanionia is a bryophyte that doubled 
Fig. 2. Density of seedlings/propagules germinated from (A) soil from under intact reference vegetation and from within the tracks, (B) seeds and propagules (seed rain) collected in mats placed within intact reference vegetation and within the tracks. The top layer of soil containing the seed bank was probably removed from the vegetation by the vehicle. This natural seed bank is very important as a source of local seeds for revegetation. See Appendices A and B for details on methods and results.

A

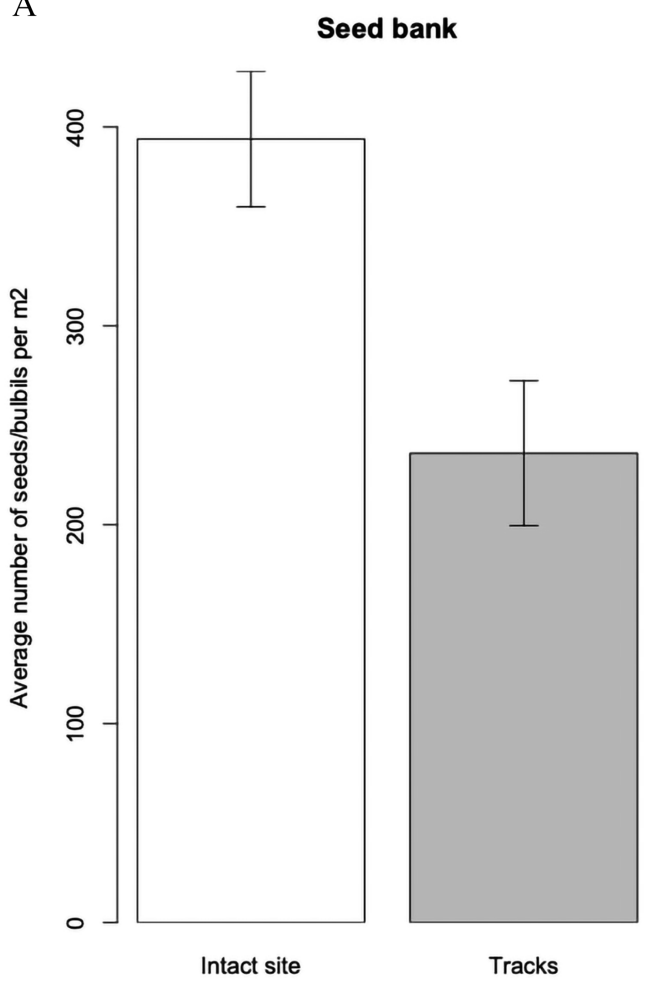

B

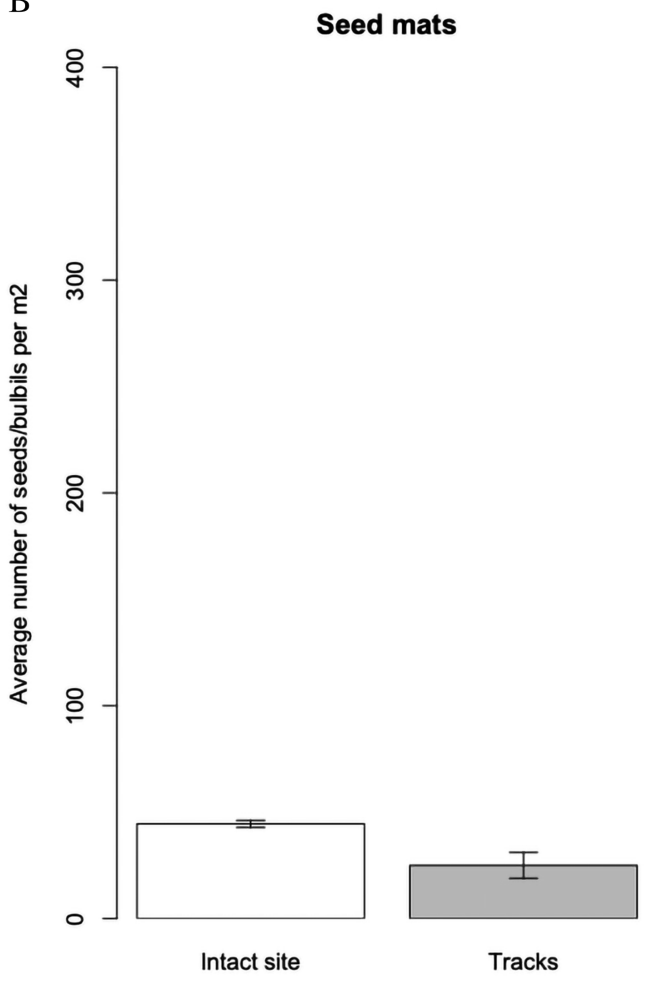

in abundance after shrub death due to increased snow in a nearby field experiment, and is likely to play an important role in this revegetation experiment. Similarly, the unidentified young graminoids most likely were of the same species we could identify as mature plant species, namely Luzula arcuata subsp. confusa and Alopecurus magellanicus, but we cannot exclude that they were also one of the other species present in the study site, e.g., Luzula nivalis, and Poa spp.

\section{Experimental regeneration treatments}

The following six treatments were applied randomly to the defined plots inside the vehicle tracks once only, in July 2010. Each treatment was applied to 10 plots, resulting in 60 experimental plots plus 10 unmanipulated control plots. The treatments were chosen to be realistic and could be applied on a large scale in the tundra if necessary.

The fertilisation treatment $(\mathrm{F})$ consisted of a diluted commercial plant fertiliser. The fertiliser (Substral Plantenæring from The Scotts Company Nordic AS, 0214 Oslo, Norway) contained $6 \%$ nitrogen, $1.3 \%$ phosphorus and $5 \%$ potassium. Arctic tundra communities have a natural nitrogen uptake of $0.752-1 \mathrm{~g}$ per $\mathrm{m}^{2}$ per year (Chapin et al. 1988; Baddeley et al. 1994). The fertiliser treatment $(17.5 \mathrm{~mL})$ was sprayed evenly onto a $0.25 \mathrm{~m}^{2}$ covering the plots manually with a spray bottle once at the beginning of the first growing season, similar to previous fertilisation experiments in the Arctic (Bigger and Oechel 1982; 
Fig. 3. Cover of each species/group (including bare ground and animal droppings, i.e., unvegetated portions) observed in the reference vegetation in 2010 and the treatment plots in the tracks in 2018. Treatment codes: C, control; F, fertilizer; FG, fertilizer $\times$ garden cloth; G, garden cloth; P, plant cutting addition; S, seed/bulbil addition; T, tilling. Please note that the reference vegetation composition was recorded in another year (2010) and with another methodology (point framing) than the composition in the treatment plots (2018, visual cover estimates) and may, hence, only be compared qualitatively together here and with Supplementary Table $S 1^{1}$, i.e., to illustrate the obvious differences in composition between the groups. Both Pedicularis dasyantha and Pedicularis hirsuta are present but not abundant in the surrounding vegetation, but note that Pedicularis dasyantha is only found here in the reference vegetation and Pedicularis hirsuta only in plots of treatment "S". Graminoids that were too immature to be identified (mainly in 2010) were grouped into "Graminoid young" group. Bryophytes were not identified in the field in this study, but species present in the surroundings in 2017 were, in descending order of abundance: Sanionia uncinata, Tomentypnum nitens, Hylocomium splendens, Dicranum and Distichium spp., Polytrichum spp., and Aulacomnium spp., (Mörsdorf and Cooper 2021). See Table A1 for full names of taxa.

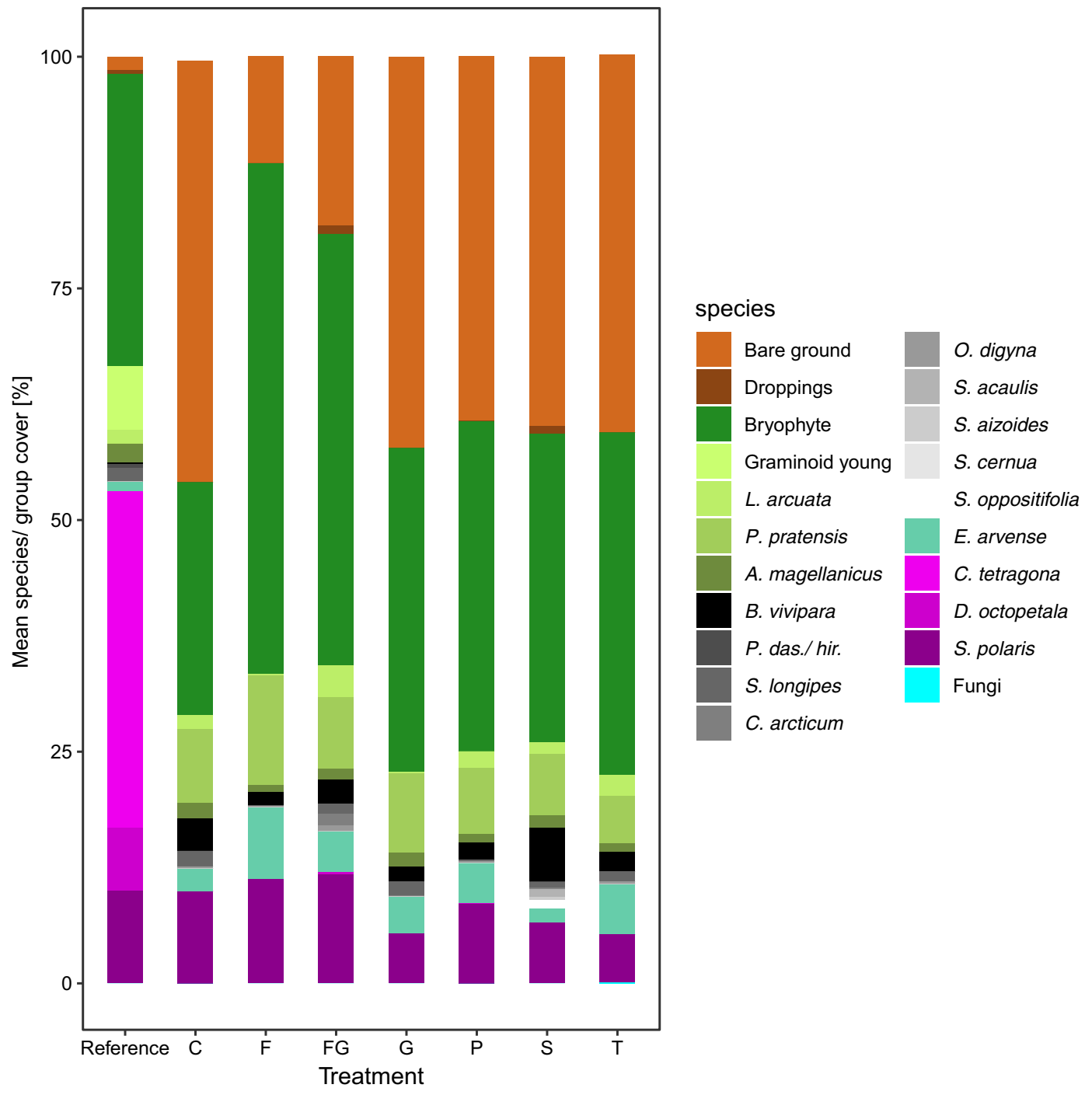


Baddeley et al. 1994; Robinson et al. 1998). We used mild amounts of fertilisation as too much in nutrient-poor soils might lead to a decrease in the number of plant individuals and percent cover (Forbes and Jefferies 1999; Gordon et al. 2001).

Treatment $G$ was the addition of a fibre cloth/garden fabric (Gardener's Supply Company 2011, Vermont, USA) spread over the plot area, exceeding it by $15 \mathrm{~cm}$ on each side and pinned down using nails. The cloths were intended to slightly increase soil temperature and moisture (https://www.gardeners.com/how-to/row-covers/5111.html), similar to a greenhouse ( $\mathrm{Gu}$ and Grogan 2020). Temperature and moisture probes (HOBO-loggers, HOBO ${ }^{\circledR}$, Massachusetts, USA) were placed $2 \mathrm{~cm}$ below the surface during July to September 2011 and showed that the fibre cloths increased temperature on average by $0.3^{\circ} \mathrm{C}$ (the mean temperature in the controls was $6{ }^{\circ} \mathrm{C}$ during this period). Relative humidity was measured by the same loggers in the same time period and was $0.1 \%$ lower in plots with cloths (based on measures from two plots only covered with cloths) compared with the plots without cloths (based on measures from four plots not covered with cloths). The cloths in treatment $G$ were left throughout the year and replaced when the snow melted in the second season. Some cloths were also replaced during the summer if we noticed damage (e.g. caused by reindeer); nevertheless, one blew away unnoticed, thus leaving treatment $G$ with nine instead of 10 replicates. We also applied a treatment using fibre cloths in combination with fertiliser (treatment FG).

Treatment $S$ included the addition of seeds and bulbils to the plots. We sowed an evenly spread mixture of 50 seeds from Silene acaulis (L.) Jacq. and 50 seeds from Saxifraga oppositifolia (L.), as well as 50 bulbils from B. vivipara that were all opportunistically gathered from the local area for this and other ongoing projects. These species are locally common. The propagules are easy to gather and relatively easy to germinate in the field (Cooper et al. 2004; Müller et al. 2011), as opposed to seeds of $C$. tetragona, which are less available because their seeds are small and their flowers face downward (thus releasing their seeds quickly), and they are known to not readily germinate in experimental settings (Alsos et al. 2013).

For treatment $\mathrm{P}$, the addition of plant cuttings, we composed a mixture of cut pieces of Salix polaris and the prostrate form of Saxifraga oppositifolia from the surroundings. These two species can propagate easily through cuttings (Hagen 2002; Hartmann et al. 2002; Hagen 2003; Cooper 2006) and were, therefore, suitable choices for this revegetation study. Approximately 1.15 litre of vegetation mixture was necessary to cover each plot. The material was sprinkled on the plot but was not held in place by any netting or cloth.

The tilling treatment $(\mathrm{T})$ was performed to aerate compacted soil using a dinner fork with two of its prongs bent downward at a $90^{\circ}$ angle in a spinning movement through the soil layer with a maximum depth of $3 \mathrm{~cm}$. An equal amount of time was spent tilling each treatment plot (approximately $1 \mathrm{~min}$ ).

\section{Statistical analyses \\ Disturbance in vehicle tracks}

To illustrate the disturbance caused by the vehicle tracks and the homogeneity of the floral composition inside the vehicle tracks, we used constrained correspondence analysis (CCA) using the vegan package (Oksanen et al. 2012) on the point-frame data from June 2010 (i.e., one year following disturbance, but before treatments were added). Constraining variables were treatment and reference vegetation, that is, whether the plots were outside the vehicle tracks. We tested the significance of the constraining variables by applying a permutation test with 999 permutations. 
Total vegetation cover

To compare the inter-annual (i.e., across the years 2010-2011-2018) development of the disturbed plots without confounding it with seasonal developmental growth, phenology, or die-back (see Supplementary Figs. S2 and $S 4^{1}$ for within-year temporal development), we concentrated on the vegetation in the experimental plots during the peak seasons on 21 July 201017 July 2011 and 20 July 2018. The effects of the different revegetation assistance methods (treatments) were modelled as total vegetation cover, defined as the sum of cover estimates per subplot for all identified vascular plant species, unidentified (young) graminoid species, and unidentified bryophyte species. For this analysis, we removed (unidentified) fungal species and droppings, as fungi only appeared in one plot, and droppings did not contribute to revegetation success (Fig. 3). It was not possible to relocate all plots in 2018; thus, the control and treatment plots for 2018 consisted of the following replicates: $\mathrm{C}(n=7), \mathrm{F}(n=8), \mathrm{FG}(n=9), \mathrm{G}(n=9), \mathrm{S}(n=10), \mathrm{P}(n=10)$, and T $(n=10)$.

The total vegetation cover data can be considered as counts, because only non-negative integer numbers were recorded as percentage cover, and the maximum total vegetation cover could be higher than $100 \%$. Hence, we used generalised mixed-effects models with Poisson distribution and log-link through the glmer function from the lme4 package in $\mathrm{R}$ (Bates et al. 2015; R Core Team 2021). The full model included the treatment by year interaction as fixed effects and random intercepts for plots (to account for pseudoreplication (Hurlbert 1984)). The residual variance of each model was visually checked for normality and heterogeneity across all predictor variables, both of which were fulfilled. Backward model selection was performed via likelihood ratio tests and AIC comparison between the full model and an additive model excluding the treatment by year interaction, with the result that the full model was selected for further interpretation of the data. Finally, we calculated simultaneous Tukey-corrected pairwise 95\% confidence intervals (CIs) using the glht function from the multcomp package (Hothorn et al. 2008) and interpreted contrasts as significant if the CIs excluded zero. Back-transformed estimated marginal means of the final model with 95\% CIs were created using the emmeans function of the multcomp package (Hothorn et al. 2008) to illustrate the total vegetation cover in Fig. 4.

\section{Results}

Disturbance in vehicle tracks

Concerning species composition prior to treatment application (i.e., point-frame data from June 2010), the permutation test of the constraining term treatment/reference in the CCA analysis was highly significant when the reference vegetation was included in the analysis $(p<0.001)$, that is, at least one of the factors in treatment/reference had a significantly different species composition than the others (Supplementary Fig. S5 ${ }^{1}$ ). When the reference vegetation term is removed from the analysis (Supplementary Fig. S6 ${ }^{1}$ ), the treatment term was no longer significant $(p=0.992)$, that is, the species composition did not differ across the treatments within the vehicle tracks (disturbed vegetation). These results indicated that the disturbed vegetation was clearly different from the reference vegetation. This difference was mainly caused by the absence of D. octopetala, C. tetragona, and bryophytes, and the predominance of bare ground in the disturbed vegetation (Fig. 3, Supplementary Figs. S5 and S6 ${ }^{1}$; Supplementary Table S1 ${ }^{1}$ ). These results further indicate that the plots in which the treatments were later assigned had no initial floral composition difference influencing the plots' trajectories (Supplementary Fig. S6 ${ }^{1}$ ).

\section{Total vegetation cover}

In the peak-season total vegetation cover analysis, the treatment $\times$ year interaction was significant, that is, the treatment effects differed across years (likelihood ratio test 
Fig. 4. Modelled percentage of plot covered by vegetation (both vascular plants and bryophytes) in peak growing season late July 2010, 2011, and 2018. Displayed are back-transformed estimates with $95 \%$ confidence intervals from a generalized linear mixed effects model (see methods for details). C, control; F, fertilizer; FG, fertilizer $\times$ garden cloth; G, garden cloth; P, plant cutting addition; S, seed/ bulbil addition; T, tilling.

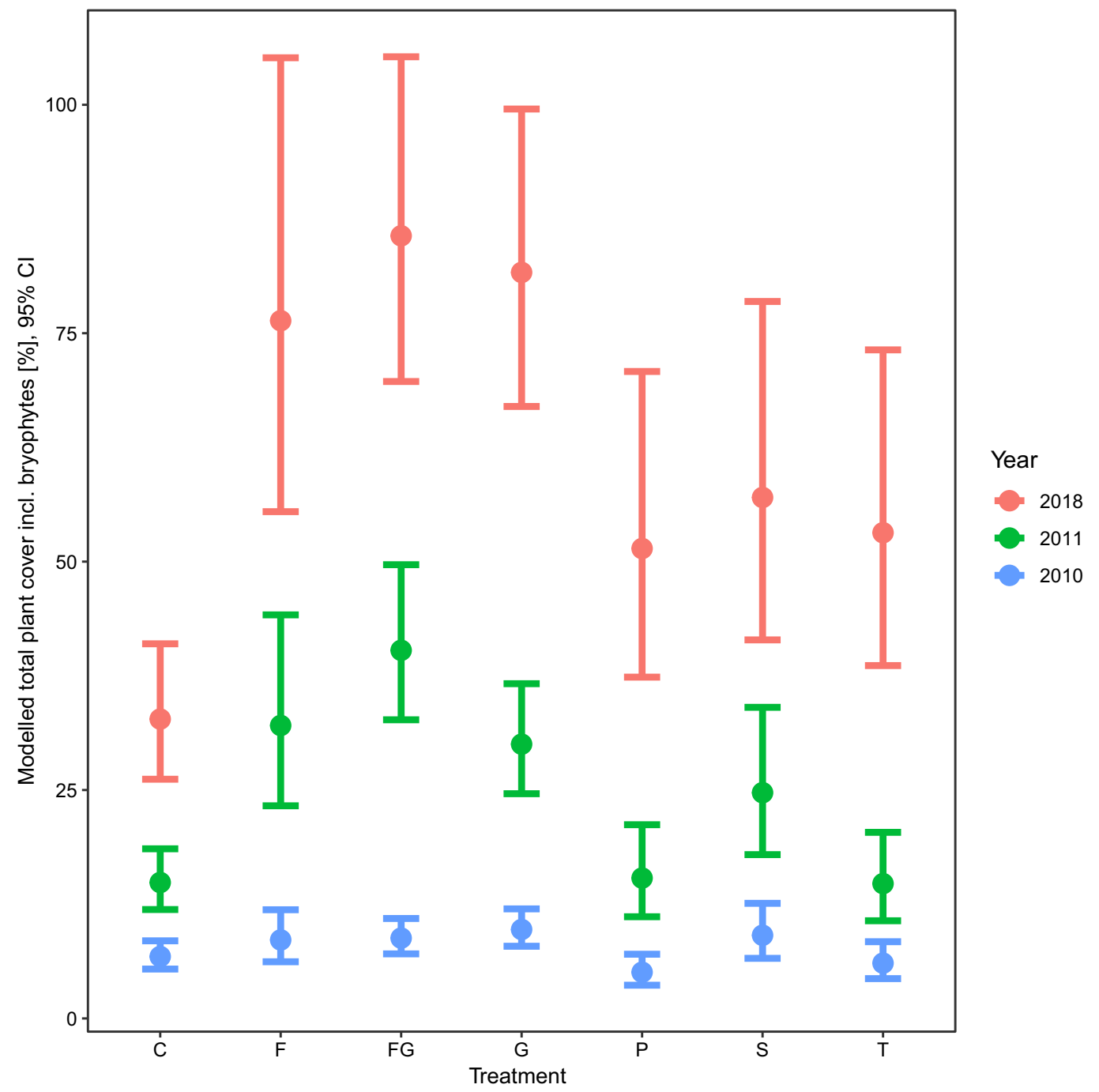

$p$-value $<0.0001)$. Indeed, the strongest effects were due to years alone (Supplementary Table S2 ${ }^{1}$, Fig. 4), that is, vegetation cover increased with time independent of treatment, albeit at different rates across treatments. In 2010, the summer of treatment application, there was no significant effect of the treatments except for treatment $\mathrm{G}$ (garden cloth), which had 1.05-1.97 (95\% CI) times higher cover than the controls.

In 2011, one year after the application of the treatments, treatments $\mathrm{F}$ (fertiliser), FG (fertiliser plus garden cloth), and G had significantly higher vegetation cover than the controls, whereas the remaining treatments were not significantly different from the controls (Fig. 4, Supplementary Table S2 ${ }^{1}$ ). Within the named three treatments, FG had significantly higher vegetation cover than $G$ but not $F$. 
In 2018, eight years after the application of the treatments, F, FG, and G had significantly higher vegetation cover than the controls, with each of the three treatments' effect sizes being approximately the same and not significantly different from each other (Fig. 4, Supplementary Table S2 ${ }^{1}$ ). Although F, FG, and G had significantly higher vegetation cover than the controls in 2018, the remaining treatments $P$ (plant cuttings), S (seeds), and $\mathrm{T}$ (tilling) tended to have higher cover, but not significantly so. Similarly, $\mathrm{P}, \mathrm{S}$, and $\mathrm{T}$ had qualitatively but not significantly lower cover than F, FG, and G.

\section{Discussion}

We systematically assisted in the regeneration of landscape scars created by off-road driving in the High Arctic Svalbard tundra. Nine years after the disturbance, the vehicle tracks were still clearly visible in the landscape. Inside the tracks, vegetation composition was significantly different from the surrounding reference vegetation. During the eightyear study period, the tracks did not regain their original vegetation composition. Vegetation cover increased with time independent of treatment, with the strongest effects due to years alone; however, the six regeneration treatments differed in their effects.

We found that adding fertiliser was the most effective treatment for increasing total vegetation cover, corroborating previous studies in cold environments (Baddeley et al. 1994; Robinson et al. 1998). Low soil nutrient availability is common in these harsh environments because of slow nutrient cycles (Callaghan et al. 2004; Walker and del Moral 2009); thus, removing this nutrient limitation is expected to be a valuable method to help regenerate the vegetation in the tracks (Krautzer et al. 2012). During the initial study year, our model found no effect between treatments during the peak season, likely because there was not enough time for the slow-growing vegetation to respond. However, detailed weekly monitoring showed an increase in vegetation cover during late summer in the two fertiliser treatments in 2010 (Supplementary Fig. S4 ${ }^{1}$ ), which was mainly caused by an increase in Poa pratensis cover. This was further enhanced during the second and ninth years after disturbance, where treatments F, G, and FG had significantly higher vegetation cover than the controls. As the total vegetation cover of $\mathrm{G}$ alone has far more bare ground in our raw data (Fig. 3, Supplementary Table S1 ${ }^{1}$ ) than that of F and FG, we interpret the effect of FG as being foremost because of fertilisation. Nevertheless, using garden cloth, mesh netting or similar cover or erosion matting as in our treatment $G$ has proved valuable in studies in other habitats (Lewis 1995; Lavendel 2002) and in cold habitats (Whitall 1995). The FG treatment showed stronger effects in 2018 than in 2011, indicating a possible increase in the effects of the treatments. It would be interesting to examine the effect of climatic differences during these seasons; however, this is beyond the scope of this study.

Most of the effects of the fertiliser treatments were due to bryophyte growth (Fig. 3). Although this study does not allow us to test this in detail because of incomplete bryophyte identification in the field, their species composition was shown to differ between the original vegetation and disturbed vehicle tracks even when vascular vegetation did not differ. We aim to test this using future monitoring of the experiment. Our findings are in line with other studies in nutrient-limited ecosystems, which have shown that the addition of fertiliser increases the growth of taxonomic groups demanding or utilising high nutrient levels, such as grasses and bryophytes (Densmore 1992; Sjögersten et al. 2010; Moulton and Gough 2011).

In any case, even though we cannot name the individual species here, to supplement the incomplete bryophyte identification and help the reader interpret our results, the bryophyte species present in the surroundings were identified in another study close to our field site in 2017 and were, in descending order of abundance: Sanionia uncinata, Tomentypnum nitens, Hylocomium splendens, Dicranum and Distichium spp., Polytrichum spp., 
and Aulacomnium spp. (Mörsdorf and Cooper 2021). Bryophyte sods have been used with considerable success in the assisted revegetation of tundra wetlands affected by vehicle tracks in the Canadian High Arctic (Forbes 1993). This shows that a better understanding of the highly significant bryophyte component is needed when conducting future studies on the regeneration of High Arctic disturbances (Lett et al. 2021; Mörsdorf and Cooper 2021).

Independent of fertilisation, we also found other ruderal species established after vehicle disturbance. For instance, Poa pratensis was not in the reference vegetation but occurred in all treatments (Fig. 3, Supplementary Table S1 ${ }^{1}$ ). Such establishment is an important step towards plant succession and further regeneration (both natural and assisted) in disturbed tundra vegetation (Fig. 3; Forbes 1994; Forbes et al. 2001; Forbes and McKendrick 2002; Hagen and Evju 2013). However, this may be interpreted as a change in vegetation composition, and the disturbance of vegetation in the area of our field site in western Svalbard may be a gateway for non-native or invasive species to naturalise because of the lack of competition in these disturbed areas.

The vehicle tracks may have removed, rather than compressed, the topmost layer of soil, leaving a severely reduced seed bank (Appendix A). Without vegetation cover, the microhabitat is less susceptible to trapping dispersing seeds (Chapin et al. 1994, Appendix B) in an already poor recruitment habitat (Bliss 1958; Havström et al. 1993; Müller et al. 2011). Although introduced seeds and bulbils in a depleted soil bank are expected to have a competitive advantage, we found only a small effect on vegetation cover, in contrast to other studies (Grant et al. 2011; Hagen and Evju 2013). Seeded species in revegetation experiments are typically fast-growing grasses that quickly provide erosion protection and vegetation cover. Such treatments have been found to both facilitate and reduce the establishment of original species (Olofsson et al. 1999; Gretarsdottir et al. 2004; Hagen et al. 2014), thus risking lower species richness than without seeding (Densmore 1992; Rydgren et al. 2016). To account for this, we collected seeds/bulbils/cuttings from the local surroundings, expecting them to be better adapted to local conditions (Grant et al. 2011) and to avoid persistent introduced species (Rydgren et al. 2016). However, there is also a risk of poor seedling survival (Ebersole 2002; Müller et al. 2011), and our seeding method might have been less than optimal in such a barren, wind-exposed, and easily eroded microhabitat. When revisiting the site shortly after adding the treatments, many of the cuttings in treatment $P$ were removed by the wind. In future studies, this may be avoided by combining seeding/addition of cuttings with a net or garden cloth (treatment G), soil addition, water, or transplant turfs (Bay and Ebersole 2006; Mehlhoop et al. 2018). Notably, Silene acaulis (also found in treatment P in 2010) and Saxifraga oppositifolia were only found in treatment S in 2011 and 2018. We did not test the extent to which seeding of non-native species may have increased vegetation cover. We suggest that in combination with fertiliser (Evans and Kershaw 1989), seeding local species might lead to a more diverse vegetation type instead of the predominance of bryophytes in the fertiliser treatments, although in our case, it would not match the vegetation type in the reference as the three added species were are not or were almost not present in the reference vegetation. Based on this study, we cannot interpret any specific effects of tilling in treatment $\mathrm{T}$ except fungus appearance in one plot, possibly due to exposure of mycorrhiza or spores to fertile soil.

Despite trialing the various assisted regeneration methods, the strongest effects on total vegetation cover were due to time alone (i.e. years), meaning that vegetation cover increased with time, independent of treatment. Our findings confirm the results of largescale alpine restoration projects (Hagen et al. 2019), where disturbing areas follow succession and are revegetated even without the application of assisted restoration methods (Walker and Walker 1991; Chapin et al. 1994). Vegetation cover itself can be advantageous, especially in Arctic-alpine environments (Krautzer et al. 2012), to prevent further loss of 
topsoil due to soil erosion, which may even surpass the initial disturbances (Vasil'Evskaya et al. 2006). Such a cover may also aid the area with increased moisture, nutrients, and microsites for germination (Urbanska and Chambers 2002).

This study demonstrated that tundra vegetation and Cassiope heath are particularly vulnerable to off-road tracked vehicles driving on unfrozen ground. Short growing seasons, low temperatures, strong winds, and often low nutrient availability slow down germination and establishment processes, and hence, the vegetation needs longer to recover (Kevan et al. 1995; Urbanska and Chambers 2002; Bay and Ebersole 2006). In addition, Cassiope heath is one of the less frequent of the common vegetation types in the study area. This is a wellestablished vegetation type, not typical "pioneer" vegetation, and slow to regenerate after disturbance (Speed et al. 2010). This may be partly due to Cassiope and Dryas species having low rates of seed germination (Müller et al. 2011) and establishment (Cooper et al. 2004), and generally very slow growth (Mallik et al. 2011). Within the regeneration treatments, none were successful in advocating the growth of the dwarf shrubs Dryas and Cassiope. The lack of revegetation of these two locally common species exemplifies the conclusion of the experiment that the slow-growing Arctic vegetation, with important species possibly having low germination efficiency, needs a time window much longer than the nine years used in this study until they can recreate a Cassiope heath.

Even after nearly a decade following disturbance and despite various active regeneration treatments, our study clearly shows that these tracks will take many decades to become completely revegetated (Supplementary Fig. $S 7^{1}$ ). Time stands out as the most important factor for the regeneration of slow-growing plant communities in cold biomes, and this should be communicated to policymakers, environmental protection officers, tracked vehicle drivers, project owners, and to the public and tourists to ensure realistic expectations of recovery time. The literature rarely reports development after long time frames, as long-term monitoring studies are rare (Evju et al. 2020). Our study is short-term, considering the successional timescale of tundra vegetation with its slow growth rates (Forbes et al. 2001), and confirms previous findings of extremely slow revegetation in the Arctic.

We did show a clear reestablishment of vegetation cover after nine years, which can be considered a success given that recovery to any state of vegetation is the goal of most regeneration schemes' mandates. However, in terms of species composition, we showed that the community of plant species that grow in the tracks does not have the same species composition as in the surroundings. Because of the low germination, establishment, and slow growth of the shrub species Cassiope and Dryas in particular, it may take many decades for the tracks to reach a species composition similar to the original vegetation if it occurs at all (Forbes et al. 2001).

Our results may provide an incentive to adjust the rules for the use of tracked vehicles at the end of the snow season. It may call for stricter local regulations, especially concerning less common vegetation types or those which take a very long time to establish, for example, Cassiope heath. The best way to avoid severe vegetation damage is to prevent it from occurring. Regulations against driving on unfrozen or snow-free ground already exist in Svalbard, as in other countries and ecosystems, but the rules may not be sufficiently enforced with consequences for rule breakers. As tundra scientists are often in the field, ITEX members and other field workers should also try to limit their own disturbance of vegetation and raise awareness locally and internationally. Unfortunately, anthropogenic disturbances have been increasing globally since the 1960s (Kevan et al. 1995), but we hope that the current United Nations Decade on Ecosystem Restoration (https:// www.decadeonrestoration.org) will inspire a change in local authorities' and administrators' attitudes and management actions, and increase public awareness of the issue. 
The increasing amount of disturbance in the Arctic and alpine tundra, together with the low regeneration rates, should warn us to be pre-emptive and adopt policies and practices that minimise such disturbances.

\section{Funding Statement}

This study was financed by the University of Troms $\emptyset$, Svalbard Environmental Fund (grant 09/85), and the University Centre in Svalbard (UNIS).

\section{Contributors' Statement}

MN: Formal analysis, investigation, methodology, validation, visualisation, writing original draft, writing - review, and editing. PS: Formal analysis (lead), investigation, methodology, resources, validation, visualisation, writing, review, and editing. EN: Conceptualisation, formal analysis, investigation (lead), methodology, project administration, resources, validation, visualisation, writing, review, and editing. EJC: Conceptualisation (lead), funding acquisition (lead), methodology (lead), project administration, resources, supervision, validation, visualisation, writing, review, and editing.

\section{Data Availability Statement}

Data available upon request.

\section{Acknowledgements}

We thank Pernille B. Eidesen and Eike Müller for useful discussions during the planning stage, as well as Isla Myers-Smith, Tore Magnussen, and Sofia Kapla for participating in fieldwork. Special thanks also to Leidulf Lund at the Climate Laboratory Holt in Troms $\emptyset$ and Svein Øivind Solberg. We are especially thankful to Bruce C. Forbes, anonymous reviewers, and editors for improving the manuscript with their constructive comments.

\section{References}

Abele, G., Brown, J., and Brewer, M.C. 1984. Long-term effects of off-road vehicle traffic on tundra terrain. J. Terramechanics, 21(3): 283-294. doi: 10.1016/0022-4898(84)90037-5.

Alsos, I.G., Müller, E., and Eidesen, P.B. (2013). Germinating seeds or bulbils in 87 of 113 tested Arctic species indicate potential for ex situ seed bank storage. Polar Biology, 36(6): 819-830. doi: 10.1007/s00300-013-1307-7.

Babb, T.A., and Bliss, L.C. 1974. Effects of physical disturbance on Arctic vegetation in the Queen Elizabeth Islands. J. Appl. Ecol. 11(2): 549. doi: 10.2307/2402208.

Baddeley, J.A., Woodin, S.J., and Alexander, I.J. 1994. Effects of increased nitrogen and phosphorus availability on the photosynthesis and nutrient relations of three Arctic dwarf shrubs from Svalbard. Funct. Ecol. 8(6): 676-685.

Barak, R.S., Williams, E.W., Hipp, A.L., Bowles, M.L., Carr, G.M., Sherman, R., and Larkin, D.J. 2017. Restored tallgrass prairies have reduced phylogenetic diversity compared with remnants. J. Appl. Ecol. 54(4): 1080-1090. doi: 10.1111/1365-2664.12881.

Bash, J.S., and Ryan, C.M. 2002. Stream restoration and enhancement projects: is anyone monitoring? Environ. Manage. 29(6): 877-885. doi: 10.1007/s00267-001-0066-3.

Bates, D., Mächler, M., Bolker, B., and Walker, S. 2015. Fitting linear mixed-effects models using lme4. J. Stat. Softw. 67(1): 48. doi: 10.18637/jss.v067.i01.

Bay, R.F., and Ebersole, J.J. 2006. Success of turf transplants in restoring Alpine trails, Colorado, U.S.A. Arct. Antarct. Alp. Res. 38(2): 173-178. doi: 10.1657/1523-0430(2006)38[173:SOTTIR]2.0.CO;2.

Bigger, C.M., and Oechel, W.C., 1982. Nutrient effect on maximum photosynthesis in arctic plants. Holarctic Ecology, 5(2): 158-163.

Bliss, L.C. 1958. Seed germination in Arctic and Alpine species Arctic, 11(3): 180-188.

Callaghan, T.V., Bjorn, L.O., Chernov, Y., Chapin, T., Christensen, T.R., Huntley, B., et al. 2004. Effects on the structure of arctic ecosystems in the short- and long-term perspectives. Ambio, 33(7): 436-447. doi: 10.1639/00447447(2004)033[0436:Eotsoa]2.0.Co;2.

Chapin, F.S., and Chapin, M.C. 1980. Revegetation of an Arctic disturbed site by native tundra species. J. Appl. Ecol. 17(2): 449-456. doi: 10.2307/2402339.

Chapin, F.S., Fetcher, N., Kielland, K., Everett, K.R., and Linkins, A.E. 1988. Productivity and nutrient cycling of Alaskan tundra: enhancement by flowing soil water. Ecology, 69(3): 693-702.

Chapin, F.S., Walker, L.R., Fastie, C.L., and Sharman, L.C. 1994. Mechanisms of primary succession following deglaciation at Glacier Bay, Alaska. Ecol. Monogr. 64(2): 149-175. 
Cooper, E.J. 2006. Reindeer grazing reduces seed and propagule bank in the High Arctic. Can. J. Botany. 84(11): 1740-1752. doi: 10.1139/b06-127

Cooper, E.J., Alsos, I.G., Hagen, D., Smith, F.M., Coulson, S.J., and Hodkinson, I.D., 2004. Plant recruitment in the High Arctic: Seed bank and seedling emergence on Svalbard. J. Veg. Sci. 15(1): 115-124. doi: 10.1111/j.16541103.2004.tb02244.x.

Densmore, R.V. 1992. Succession on an Alaskan tundra disturbance with and without assisted revegetation with grass. Arct. Alp. Res. 24(3): 238-243.

Deshaies, A., Boudreau, S., and Harper, K.A. 2009. Assisted revegetation in a subarctic environment: effects of fertilization on the performance of three indigenous plant species. Arct. Antarct. Alp. Res. 41(4): 434-441. doi: 10.1657/1938-4246-41.4.434.

Ebersole, J.J. 2002. Recovery of alpine vegetation on small, denuded plots, Niwot Ridge, Colorado, U.S.A. Arct. Antarct. Alp. Res. 34(4): 389. doi: 10.2307/1552196.

Elvebakk, A. 2005. A vegetation map of Svalbard on the scale 1:3.5 mill. Phytocoenologia, 35: 951-967. doi: 10.1127| 0340-269X/2005/0035-0951.

Emers, M., Jorgenson, J.C., and Raynolds, M.K. 1995. Response of arctic tundra plant communities to winter vehicle disturbance. Can. J. Botany, 73(6): 905-917. doi: 10.1139/b95-099.

Evans, K.E., and Kershaw, G.P. 1989. Productivity of agronomic and native plants under various fertilizer and seed application rates on a simulated transport corridor, Fort Norman, Northwest Territories. In Proceedings of the conference: Reclamation, a global perspective. Alberta Conservation and Reclamation Council. Report No. RRTAC. pp. 89-82.

Evju, M., Hagen, D., Kyrkjeeide, M., and Junker Koehler, B. 2020. Learning from scientific literature: Can indicators for measuring success be standardized in "on the ground" restoration?: Indicators of restoration outcome. Restor. Ecol. 28(3): 519-531. doi: 10.1111/rec.13149.

Felix, N. A., and Raynolds, M. K. 1989. The effects of winter seismic trails on tundra vegetation in northeastern Alaska, U.S.A. Arct. Alp. Res. 21(2): 188-202.

Firlotte, N., and Staniforth, R.J.1995. Strategies for revegetation of disturbed gravel areas in climate stressed subarctic environments with special reference to Churchill, Manitoba, Canada: a literature review. Clim. Res. 5(1): 49-52.

Forbes, B.C. 1992. Tundra disturbance studies, I: Long-term effects of vehicles on species richness and biomass. Environ. Conserv. 19: 48-58. doi: 10.1017/S0376892900030241.

Forbes, B.C. 1993. Small-scale wetland restoration in the High Arctic: a long-term perspective. Restor. Ecol. 1(1): 59-68. doi: 10.1111/j.1526-100X.1993.tb00009.x.

Forbes, B.C. 1994. The importance of bryophytes in the classification of human-disturbed high arctic vegetation. J. Veg. Sci. 5(6): 877-884. doi: 10.2307/3236200.

Forbes, B.C., Ebersole, J.J., and Strandberg, B., 2001. Anthropogenic disturbance and patch dynamics in circumpolar Arctic ecosystems. Conserv. Biol. 15(4): 954-969.

Forbes, B.C., and Jefferies, R.L. 1999. Revegetation of disturbed arctic sites: constraints and applications. Biol. Conserv. 88(1): 15-24. doi: 10.1016/s0006-3207(98)00095-0.

Forbes, B.C., and McKendrick, J.D. 2002. Polar tundra. In Handbook of Ecological Restoration. Edited by A.J. Davy and M. Perrow. Cambridge University Press, Cambridge. pp. 355-375.

Gardener's Supply Company. 2011. Using garden fabric (row covers). Gardener's Supply Company, Vermont, USA.

Gordon, C., Wynn, J., and Woodin, S. 2001. Impacts of increased nitrogen supply on high Arctic heath: the importance of bryophytes and phosphorus availability. New Phytol. 149(3): 461-471.

Grant, A.S., Nelson, C.R., Switalski, T.A., and Rinehart, S.M. 2011. Restoration of native plant communities after road decommissioning in the Rocky Mountains: Effect of seed-mix composition on vegetative establishment. Restor. Ecol. 19(201): 160-169. doi: 10.1111/j.1526-100x.2010.00736.x.

Gretarsdottir, J., Aradottir, A.L., Vandvik, V., Heegaard, E., and Birks, H.J.B. 2004. Long-term effects of reclamation treatments on plant succession in Iceland. Restor. Ecol. 12(2): 268-278. doi: 10.1111/j.1061-2971.2004.00371.x.

Gu, Q., and Grogan, P. 2020. Responses of low Arctic tundra plant species to experimental manipulations: Differences between abiotic and biotic factors and between short- and long-term effects. Arct. Antarct. Alp. Res. 52(1): 524-540. doi: 10.1080/15230430.2020.1815360.

Hadač, E. 1946. The Plant-communities of Sassen Quarter, Vestspitbergen. Societatis Botanicae Čechoslovacae.

Hadač, E. 1989. Notes on plant communities of Spitsbergen. Folia Geobotanica et Phytotaxonomica. 24(2): 131-169. doi: $10.1007 /$ BF02853039.

Hagen, D. 2002. Propagation of native Arctic and alpine species with a restoration potential. Polar Res. 21(1): 37-47. Hagen, D. 2003. Assisted recovery of disturbed arctic and alpine vegetation: an integrated approach. Norwegian University of Science and Technology.

Hagen, D., and Evju, M. 2013. Using short-term monitoring data to achieve goals in a large-scale restoration. Ecol. Soc. 18(3). doi: 10.5751/es-05769-180329.

Hagen, D., Evju, M., Mehlhoop, A.C., Olsen, S.L., and Myklebost, H.E. 2019. Vegetasjonen etablerer seg godt på restaurerte arealer i Hjerkinn skytefelt. Norsk institutt for naturforskning. Available from http://hdl.handle.net/ $11250 / 2632807$.

Hagen, D., Hansen, T.-I., Graae, B.J., and Rydgren, K. 2014. To seed or not to seed in alpine restoration: introduced grass species outcompete rather than facilitate native species. Ecol. Eng. 64: 255-261. doi: 10.1016/ j.ecoleng.2013.12.030.

Hartmann, A., Kester, D., Davies, F., and Geneve, R., 2002. Principles of propagation cutting. Pearson Education, Inc., Publishing as Prentice Hall, One Lake Street, Upper Saddle River, NJ. pp. 277-323. 
Havström, M., Callaghan, T.V., and Jonasson, S. 1993. Differential growth responses of Cassiope tetragona, an Arctic dwarf-shrub, to environmental perturbations among three contrasting high- and subarctic sites. Oikos, 66(3): 389-402.

Hothorn, T., Bretz, F., and Westfall, P. 2008. Simultaneous inference in general parametric models. Biom. J. 50(3): 346-363. doi: 10.1002/bimj.200810425.

Hurlbert, S.H. 1984. Pseudoreplication and the design of ecological field experiments. Ecol. Monogr. 54(2): 187-211. doi: $10.2307 / 1942661$

Kevan, P.G., Forbes, B.C., Kevan, S.M., and Behan-Pelletier, V. 1995. Vehicle tracks on High Arctic tundra: their effects on the soil, vegetation, and soil arthropods. J. Appl. Ecol. 32(3): 655-667. doi: 10.2307/2404660.

Klokk, T., and Rønning, O.I. 1987. Revegetation experiments at Ny-Ålesund, Spitsbergen, Svalbard. Arct. Alp. Res. 19(4): 549-553. doi: 10.1080/00040851.1987.12002640.

Komarkova, K. 1983. Recovery of plant communities and summer thaw in the 1949 Fish Creek Test Well I, Arctic Alaska. In Proceedings of the Fourth International Conference on Permafrost, July 17-23, 1983. National Academy Press, Washington, DC. pp. 645-650.

Krautzer, B., Uhlig, C., Helmut, W., Krautzer, B., Uhlig, C., and Wittmann, H., 2012. Restoration of arctic-alpine ecosystems. In Restoration Ecology: The New Frontier, 2nd edition. Edited by J.V. Andel and J. Aronson. Blackwell Publ. Ltd.. pp. 189-202.

Låg, J. 1986. Jordbunnsgrunnlaget for plantevekst på Svalbard. Årbok. Det Norske Videnskapsakademi, Oslo.

Lavendel, B. 2002. The business of ecological restoration. Ecol. Restor. 20(3): 173-178. doi: 10.3368/er.20.3.173.

Lett, S., Jónsdóttir, I.S., Becker-Scarpitta, A., Christiansen, C.T., During, H., Ekelund, F., et al. 2021. Can bryophyte groups increase functional resolution in tundra ecosystems? Arct. Sci. doi: 10.1139/as-2020-0057.

Lewis, L. 1995. Olympic national forest partnerships for slope repair and erosion control. Restor. Manag. Notes, 13: 37-39.

Li, Q., Ayers, P., and Anderson, A. 2007. Prediction of impacts of wheeled vehicles on terrain. J. Terramechanics 44(2): 205-215.

Mallik, A.U., Wdowiak, J.V., and Cooper, E.J., 2011. Growth and reproductive responses of Cassiope tetragona, a circumpolar evergreen shrub, to experimentally delayed snowmelt. Arct. Antarct. Alp. Res. 43(3): 404-409. doi: 10.1657/1938-4246-43.3.404.

MEA. 2005. Millennium Ecosystem Assessment, 2005. Ecosystems and Human Well-being: Synthesis. Island Press, Washington, DC.

Mehlhoop, A.C., Evju, M., and Hagen, D. 2018. Transplanting turfs to facilitate recovery in a low-alpine environment-What matters? Appl. Veg. Sci. 21(4): 615-625. doi: 10.1111/avsc.12398.

MET Norway. 2021. Data from The Norwegian Meteorological Institute. Available from https://www.met.no/en/freemeteorological-data/Download-services.

Miller, J., and Hobbs, R. 2007. Habitat Restoration-Do We Know What We're Doing? Restor. Ecol. 15: 382-390. doi: 10.1111/j.1526-100X.2007.00234.X.

Mörsdorf, M.A., and Cooper, E.J. 2021. Habitat determines plant community responses to climate change in the High Arctic. Arct. Sci. doi: 10.1139/AS-2020-0054.

Moulton, C.A., and Gough, L. 2011. Effects of soil nutrient availability on the role of sexual reproduction in an Alaskan tundra plant community. Arct. Antarct. Alp. Res. 43(4): 612-620. doi: 10.1657/1938-4246-43.4.612.

Müller, E., Cooper, E.J., and Alsos, I.G. 2011. Germinability of arctic plants is high in perceived optimal conditions but low in the field. Botany, 89(5): 337-348. doi: 10.1139/b11-022.

Oksanen, J., Blanchet, F.G., Kindt, R., Legendre, P., Minchin, P., O’Hara, R.B., et al. 2012. Vegan: community ecology package. The R package, version 2.0-2.

Olofsson, J., Moen, J., and Oksanen, L. 1999. On the balance between positive and negative plant interactions in harsh environments. OIKOS, 86(3): 539-543.

Onipchenko, V.G., Makarov, M.I., Akhmetzhanova, A.A., Soudzilovskaia, N.A., Aibazova, F.U., Elkanova, M.K., et al. 2012. Alpine plant functional group responses to fertiliser addition depend on abiotic regime and community composition. Plant Soil, 357(1): 103-115. doi: 10.1007/s11104-012-1146-2.

R Core Team. 2021. R: A language and environment for statistical computing. R Foundation for Statistical Computing, Vienna, Austria. Available from https://www.R-project.org/.

Racine, C.H., and Ahlstrand, G.M. 1991. Thaw response of tussock-shrub tundra to experimental all-terrain vehicle disturbances in South-Central Alaska. Arctic, 44(1): 31-37.

Rickard, W.E., and Brown, J. 1974. Effects of vehicles on arctic tundra. Environ. Conserv. 1(1): 55-62.

Robinson, C.H., Wookey, P.A., Lee, J.A., Callaghan, T.V., and Press, M.C. 1998. Plant community responses to simulated environmental change at a high arctic polar semi-desert. Ecology, 79(3): 856-866. doi: 10.1890/00129658(1998)079[0856:pcrtse]2.0.co;2.

Rozema, J., Weijers, S., Broekman, R., Blokker, P., Buizer, B., Werleman, C., et al. 2009. Annual growth of Cassiope tetragona as a proxy for Arctic climate: developing correlative and experimental transfer functions to reconstruct past summer temperature on a millennial time scale. Glob. Change Biol. 15(7): 1703-1715.

Rydgren, K., Auestad, I., Hamre, L.N., Hagen, D., Rosef, L., and Skjerdal, G. 2016. Long-term persistence of seeded grass species: an unwanted side effect of ecological restoration. Environ Sci Pollut Res. 23(14): 13591-13597. doi: 10.1007/s11356-015-4161-z. PMID: 25687605.

Sjögersten, S., Kuijper, D.P.J., Van Der Wal, R., Loonen, M.J.J.E., Huiskes, A.H.L., and Woodin, S.J. 2010. Nitrogen transfer between herbivores and their forage species. Polar Biology, 33(9): 1195-1203. doi: 10.1007/s00300-0100809-9. 
Slaughter, C., Racine, C., Walker, D., Johnson, L., and Abele, G. 1990. Use of off-road vehicles and mitigation of effects in Alaska permafrost environments: a review. Environ. Manag. 14(1): 63-72. doi: 10.1007/bf02394020.

Speed, J.D.M., Cooper, E.J., Jónsdóttir, I.S., Van Der Wal, R., and Woodin, S.J. 2010. Plant community properties predict vegetation resilience to herbivore disturbance in the Arctic. J. Ecol. 98(5): 1002-1013. doi: 10.1111/j.13652745.2010.01685.x.

Stetson, F. 1996. Extend your garden season: Row covers and mulches. Storey Publishing.

Suding, K.N. 2011. Toward an era of restoration in ecology: successes, failures, and opportunities ahead. Ann. Rev. Ecol. Evol. Syst. 42: 465-487. doi: 10.1146/annurev-ecolsys-102710-145115.

Theisen, F., and Brude, O.W. 1998. Evaluering av områdevernet på Svalbard : representativitet og behov for ytterligere vern. Meddelelser Norsk Polarinstitutt. 153.

Urbanska, K.M., and Chambers, J.C. 2002. High-elevation ecosystems. Handbook Ecol. Restor. 2: 376-400.

Vasil'Evskaya, V.D., Grigor'ev, V.Y., and Pogozheva, E.A. 2006. Relationships between soil and vegetation characteristics of tundra ecosystems and their use to assess soil resilience, degradation, and rehabilitation potentials. Eurasian Soil Sci. 39(3): 314-323. doi: 10.1134/s1064229306030112.

Vloon, C.C., Evju, M., Klanderud, K., and Hagen, D. 2021. Alpine restoration: planting and seeding of native species facilitate vegetation recovery. Restor. Ecol. doi: 10.1111/rec.13479.

Walker, D.A., Raynolds, M.K., Daniëls, F.J.A., Einarsson, E., Elvebakk, A., and Gould, W.A., et al. 2005. The circumpolar Arctic vegetation map. J. Veg. Sci. 16(3): 267-282.

Walker, D.A., and Walker, M.D. 1991. History and pattern of disturbance in Alaskan Arctic terrestrial ecosystems: A hierarchical approach to analysing landscape change. J. Appl. Ecol. 28(1): 244-276.

Walker, L., and del Moral, R. 2009. Transition dynamics in succession: Implications for rates, trajectories, and restoration. In New models for ecosystem dynamics and restoration. Edited by R.J.S. Hobbs and K.N. Suding. Island Press, Washington, USA. pp. 33-49.

Whitall, D. 1995. High alpine restoration work at McDonald Basin. Ecol. Restor. 13(1): 29-31. doi: 10.3368/er.13.1.29.

Wilson, S.D., and Gerry, A.K. 1995. Strategies for mixed-grass prairie restoration: herbicide, tilling, and nitrogen manipulation. Restor. Ecol. 3(4): 290-298. doi: 10.1111/j.1526-100X.1995.tb00096.x.

\section{Appendix A. Disturbance effect on the natural seed bank Methods}

To evaluate the seed bank in the disturbed tracks and the reference vegetation, we sampled soil in two rows on each side of the tracks and two rows within each track in 2010. We used a $3.5 \mathrm{~cm}$ wide corer to a depth of $2 \mathrm{~cm}$ (approximately 30 cores per row, but some spots in the tracks contained too many stones to make coring possible, in total $n=243\left(2338 \mathrm{~cm}^{2}\right)$. The soil cores in the reference vegetation were evenly distributed between Cassiope-rich and Cassiope-poor vegetation to cover the complete spectrum of the site. The soil cores were collected in July and August 2010, placed on filter paper into Petri dishes with lids, and kept at $-5{ }^{\circ} \mathrm{C}$ without light for another seven weeks to stratify the seeds/bulbils. The soil was then acclimatised at $+0.5{ }^{\circ} \mathrm{C}$ for four days and at $+5{ }^{\circ} \mathrm{C}$ for four days. The Petri dishes were moved into a phytotron and kept at $+18{ }^{\circ} \mathrm{C}$ for 12 weeks with $24 \mathrm{~h}$ of light $(150 \mu \mathrm{mol})$ to simulate the germination period in Svalbard (Cooper et al. 2004). The soil was moistened every third day and the seedlings and seedling survival were registered once per week. Germinating seedlings were replanted into small pots and remarked to easily distinguish between different species and to determine whether they were grown from seeds, bulbils, or cuttings. In this study, we used the data from the germinating seeds and bulbils but did not include vegetative growth from cuttings. Hereafter, we use the term "seedlings" for all germinating seeds and bulbils.

The number of observed seedlings emerging from each soil core was treated as counts, and a zero-inflated Poisson model was needed because of the excessive number of zeroes (i.e., approximately $50 \%$ of all collected soil cores had no observed seedling emergence). The model we used was a mixture model that modelled the likelihood of a count being zero for each of the two groups (inside and outside of the tracks, i.e., soil cores collected from under-disturbed and undisturbed vegetation) independently from the counts observed in non-zero cases. The likelihood of a count being zero was drawn from a Bernoulli distribution for each group separately, and the regression parameter for non-zero cases was drawn 
from a Poisson distribution with a log link. We used a Bayesian approach with JAGS (Plummer 2003) and the runjags package (Denwood 2016) in R v. 3.4.1 (R Core Team 2021).

Because we had no prior knowledge or expectations of the potential effect of belt wagon disturbance on seed bank density, we used marginally informative reference prior distributions and initial values. Two Markov chain Monte Carlo (MCMC) chains with 10000 samples each were used. After running the sampler, we observed that the two chains converged (visually and Gelman-Rubin statistics $<1.05$ ), and that the effective sample size was $>1000$. In cases where the effective sample size was $<1000$, we added a further 10000 samples to each chain until it was $>1000$, which was the case only once more. All further calculations were performed on the MCMC chains produced by the JAGS and the highest posterior density (HPD) intervals and means extracted from those chains.

To calculate the absolute modelled counts per group, we took the inverse logit of the modelled non-zero counts and multiplied it with its estimated proportion of being non-zero (i.e., the non-zero probability).

Because of the soil core sampling pattern along transects within or parallel to the vehicle tracks, we included the variable 'distance from west to east' in metres as a continuous additive term in the model. Because that term was insignificant (i.e., very small and including zero), we excluded it from the analysis.

\section{Results and discussion}

The proportion of non-zero counts was significantly higher in the undisturbed (HPD $0.59-0.8$ ) than in the disturbed vegetation (HPD 0.22-0.45). The number of emerging seedlings in undisturbed vegetation (non-zero counts) was significantly higher than in disturbed vegetation (inverse logit effect size HPD 1.03-2.19). On average, per sample 0.47 seedlings germinated in disturbed (HPD 0.32-0.65), and 1.49 in undisturbed vegetation (HPD 1.21-1.75). These lower values in the disturbed area were probably due to the removal of the uppermost soil layer containing a high seed density by the tracked vehicle's belt (Kinugasa and Oda 2014).

The dominant germinating species were Bistorta vivipara and Luzula arctica (Table A1 below). Two of the most common plants in the reference vegetation were the shrubs Dryas sp. and Cassiope sp. (Figs. 3 and 4 in the main text), which did not germinate in our soil seedbank trials, which may be due to the thermophilic or transient nature of the seeds of these species (Fox 1983; McGraw and Antonovics 1983; Molau and Larsson 2000; Cooper et al. 2004).

Seed banks are important reservoirs for vegetation recovery after disturbances in the Arctic (Cargill and Chapin 1987; Gartner et al. 1983; Ebersole 1989). Our data showed that removal of the top layer of soil by the tracked vehicle negatively affected the density of the germinable soil seedbank. The species that germinated from the soil seedbank were herbs and graminoids, which were functional types that tended to germinate easily but were not dominant in the reference vegetation. The dominant species in undisturbed vegetation were shrubs, which tended to have lower germination rates. This mismatch indicates that any revegetation from seedling germination from the soil seed bank would be at lower densities and of different taxa in the disturbed tracks than in the reference vegetation. Vegetative growth of plants in the tracks from the reference vegetation is therefore crucial for recovery. 
Table A1. Soil seed bank germination of seeds and bulbils per $\mathrm{m}^{2}$. Species composition of germinating seedlings and propagules from seeds and bulbils collected with soil cores in 2011 in reference vegetation (outside the tracks, $n=119$ soil cores) and disturbed vegetation (inside the tracks, $n=124$ soil cores).

\begin{tabular}{|c|c|c|c|}
\hline Functional Type & Species & $\begin{array}{l}\text { Reference } \\
\text { Seedlings \& } \\
\text { propagules/m² } \\
\text { Total }(n=124)\end{array}$ & $\begin{array}{l}\text { Disturbed } \\
\text { Seedlings \& } \\
\text { propagules } / \mathrm{m}^{2} \\
(n=119)\end{array}$ \\
\hline \multirow{7}{*}{ Graminoids } & Alopecurus magellanicus & 9 & 0 \\
\hline & Deschampsia alpina & 8 & 9 \\
\hline & Deschampsia sukatschewii ssp. borealis & 25 & 0 \\
\hline & Luzula confusa & 84 & 61 \\
\hline & Luzula arctica & 8 & 17 \\
\hline & Poa pratensis & 9 & 9 \\
\hline & Total graminoids & 142 & 96 \\
\hline \multirow[t]{9}{*}{ Herbs } & Bistorta vivipara & 186 & 122 \\
\hline & Cardamine bellidifolia & 0 & 9 \\
\hline & Cerastium arcticum & 8 & 0 \\
\hline & Equisetum arvense ssp. alpestre & 9 & 0 \\
\hline & Oxyria digyna & 16 & 0 \\
\hline & Papaver dahlianum & 9 & 0 \\
\hline & Total herbs & 228 & 131 \\
\hline & Unidentified to species & 42 & 9 \\
\hline & Sum & 411 & 236 \\
\hline \multicolumn{2}{|c|}{ No. of germinating graminoid species } & 6 & 4 \\
\hline \multicolumn{2}{|c|}{ No. of germinating herb species } & 5 & 2 \\
\hline
\end{tabular}

\section{Appendix B. Seed influx in the reference versus disturbed tracks}

To assess the seed and propagule influx at the reference and disturbed sites, we used doormats following the ITEX manual (Molau 1996) in July 2011 to trap dispersing diaspores. The doormats were placed approximately $1 \mathrm{~m}$ from the tracks, in rows, on both sides of the tracks, and similarly inside each track, for a total of four rows of mats. They were fastened with long nails along their edges. Each row consisted of 16 seed mats, two metres apart, each $44 \times 24 \mathrm{~cm}\left(1056 \mathrm{~cm}^{2}\right)$. Thus, 32 mats were sampled, covering an area of $33,792 \mathrm{~cm}^{2}$ inside the tracks and an equal area outside the tracks. In late September 2011, the doormats were collected, rinsed with water to release their contents, filtered through a $150 \mu \mathrm{m}$ sieve, dried at $+30{ }^{\circ} \mathrm{C}$ for $24 \mathrm{~h}$, before germinating the seeds and propagules $+20^{\circ} \mathrm{C}$ for six weeks on individual Petri dishes. Seedlings of monocotyledons or dicotyledons were counted and recorded for each Petri dish.

The germinating seed and propagule influx densities revealed that the reference vegetation had $43.6 \pm 4.0$ seeds and propagules per $\mathrm{m}^{2}$, whereas the tracks had $24.6 \pm 5.9$ seeds and propagules per $\mathrm{m}^{2}, 44 \%$ less than that of the reference vegetation. The majority of species trapped by the seed mats $(>95 \%)$ were dicotyledons, and their densities were in the lower range of those found in a high alpine heath (Molau and Larsson 2000) in Swedish Lapland. The difference between values suggests that within the tracks, seed rain is limited by fewer surrounding dispersers (Speed et al. 2010), indicating that dispersal is extremely local, as the tracks were only $50 \mathrm{~cm}$ wide. 


\section{Appendix C. Measures of soil density in the study area}

Soil density was measured in late August 2011 using soil corers to evaluate soil compaction from driving on unfrozen ground. A corer with a diameter of $3 \mathrm{~cm}\left(18.8 \mathrm{~cm}^{3}\right)$ was pushed $6 \mathrm{~cm}$ into the soil layer at 30 randomly selected locations: 10 inside the tilled plots, 10 inside the untreated parts of the track, and 10 inside the surrounding reference vegetation. The soil samples were dried at $+50{ }^{\circ} \mathrm{C}$ for $24 \mathrm{~h}$ and weighed to the nearest gram. One-way analysis of variance (ANOVA) was used to test for differences in soil density between the reference vegetation, disturbed vegetation, and tilled plots.

The average soil mass in the reference site was $11.9 \mathrm{~g} \pm 1$ (SE) per core, whereas the average soil mass in the tracks was $8.8 \mathrm{~g} \pm 1.3$ (SE) per core. The soil density of the tilled plots, where the soil had been aerated in July of the previous year, had an average mass of $9.1 \mathrm{~g} \pm 1.2$. However, no significant differences were found among the three sites (one-way ANOVA, $\mathrm{F}(2,27)=2.10, p=0.141)$. These data indicate that the vehicle did not compact the soil. However, by pulling off vegetation and its roots attached to the top layer of the soil, damage to the soil and vegetation structure was done in other ways.

\section{References}

Cargill, S.M., and Chapin, F.S.I. 1987. Application of successional theory to tundra restoration - a review. Arct Alp Res. 19: 366-372.

Cooper, E.J. 2004. Out of sight, out of mind: thermal acclimation of root respiration in Arctic Ranunculus. Arct. Antarct. Alp. Res. 36: 308-313.

Cooper, E.J., Alsos, I.G., Hagen, D., Smith, F.M., Coulson, S.J., and Hodkinson, I.D. 2004. Plant recruitment in the High Arctic: seed bank and seedling emergence on Svalbard. J. Veg. Sci. 15: 115-124.

Denwood, M.J. 2016. runjags: An R package providing interface utilities, model templates, parallel computing methods and additional distributions for MCMC models in JAGS. J. Stat. Softw. 71: 1-25.

Ebersole, J.J. 1989. Role of the seed bank in providing colonizers on a tundra disturbance in Alaska. Can. J. Botany, 67: 466-471. doi: 10.1139/b89-065

Fox, J.F. 1983. Germinable seed banks of interior Alaskan tundra. Arct. Alp. Res. 15: 405-411.

Gartner, B.L., Chapin, F.S.I., and Shaver, G.R. 1983. Demographic patterns of seedling establishment and growth of native graminoids in an Alaskan tundra disturbance. J. Appl. Ecol. 20: 965-980.

Kinugasa, T., and Oda, S. 2014. Effects of vehicle track formation on soil seed banks in grasslands with different vegetation in the Mongolian steppe, Ecol. Eng. 67: 112-118.

McGraw, J.B., and Antonovics, J. 1983. Experimental ecology of Dryas octopetala ecotypes. 1. Ecotypic differentiation and life-cycle stages of selection. J. Ecol. 71, 879-897.

Molau, U. 1996. Seed rain monitoring at ITEX sites. ITEX Manual: 43-45. Available from https://www.gvsu.edu/cms4/ asset/3A8AF24B-DDCC-71FD-83D796AFC483CEEF/itexmanualfull.pdf.

Molau, U., and Larsson, E.L. 2000. Seed rain and seed bank along an alpine altitudinal gradient in Swedish Lapland. Can. J. Botany, 78: 728-747. doi: 10.1139/b00-049

Plummer, M. 2003. JAGS: a program for analysis of Bayesian graphical models using Gibbs sampling. Available from https://www.r-project.org/conferences/DSC-2003/Proceedings/Plummer.pdf

R Core Team. 2021. R: a language and environment for statistical computing. R Foundation for Statistical Computing, Vienna, Austria. Available from https://www.r-project.org/.

Speed, J.D.M., Cooper, E.J., Jónsdóttir, I.S., Van der Wal, R., and Woodin, S.J. 2010. Plant community properties predict vegetation resilience to herbivore disturbance in the Arctic. J. Ecol. 98: 1002-1013. 